\title{
Motivational and Legal Barriers of Entrepreneurship Development
}

\author{
Khaled Nawaser \\ Department of Management, Marketing \& International Business, University of Pune, India \\ E-mail: khaled1356@yahoo.com \\ Seyed Mohammad Sadeq Khaksar (Corresponding author) \\ Department of Management, University of Sistan \& Bluchestan, Iran \\ E-mail: sms_khaksar@yahoo.com \\ Fatemeh Shakhsian \\ PhD Student in Business Management, University of Payam-e-Noor, Tehran, Iran \\ E-mail: fatemeh@shakhsian.com \\ Asghar Afshar Jahanshahi \\ $\mathrm{PhD}$ Student in Business Administration, University of Pune, India \\ E-mail: Afsharasghar@yahoo.com
}

Received: May 5, 2011

Accepted: June 24, 2011

Published: November 1, 2011

doi:10.5539/ijbm.v6n11p112

URL: http://dx.doi.org/10.5539/ijbm.v6n11p112

\begin{abstract}
Nowadays, entrepreneurship is considered as an effective strategy and a milestone in multi-lateral development of countries. Preparing backgrounds for developing entrepreneurship requires presenting entrepreneurial teachings and skills on one hand and necessitates understanding and removing its obstacles and challenges as well as establishing appropriate backgrounds for developing entrepreneurial trade on the other hand. In this paper, the viewpoints of those researchers who had participated in National Conference on Entrepreneurship Management and Regional Development (Ilam University, 2009) had been analyzed and interpreted in comparison with legal and motivational obstacles and barriers effective on the development of entrepreneurship by making use of survey method and questionnaire as well. The results show that according to the researchers' viewpoint, the legal and motivational factors had terminated the development of entrepreneurship in Iran. Moreover, financial risk factor and the fear aroused from inability in management of the business were the first and last factors among motivational factors. In addition, the bank regulations and laws factor (banking interest rate, the required documents and conditions for receiving banking facilities) and the environmental rules and regulations were the first and last legal factors effective and influential in the failure of entrepreneurship development in Iran. Generally, entrepreneurship researchers are of opinion that the motivational factors are more important than legal factors in the failure of entrepreneurship development in Iran.
\end{abstract}

Keywords: Entrepreneurship, Development, Legal obstacles, Motivational barriers, Establishing business and Job opportunities

\section{Introduction}

Entrepreneurship development is a complex, long term and comprehensive process which its aim is to increase tendency, intention and taking action for performing entrepreneurial activities. In this definition, tendency means having positive thinking towards entrepreneurship and business. But entrepreneurial intention means the percentage of mature people in society who are going to establish a business for next 12 months or to support it financially. Ultimately, entrepreneurial activity means a practical activity in order to establish a business (Zali \& Razavi, 2008).

Entrepreneurship appears as a key issue and fundamental tool for economic growth (Gupta \& York, 2008) which has the ability to change the structure and regional development and it is a factor in order to increase the gross domestic production of the countries (Morris 2001). The results of the academic researches show that there is a relation among entrepreneurship, economic development and poverty reduction (Chowdhury, 2007); moreover, entrepreneurship is recognized as the major factor for the economic development of nations, provinces and local regions (Gupta \& York, 2008). Thus, economic growth and development are much in debt with the entrepreneurs who identify the opportunities and make profit from them by making efforts and endeavors (Aidis et al, 2008).

Entrepreneurship is considered as the most important tool of economic development in the advanced modern societies in a strategic prospective and tendency towards entrepreneurship has increased all over the world. For instance, national organization of entrepreneurship and developing small businesses had been established in India 
for developing and expanding entrepreneurship and the ministry of entrepreneurship had been established in Malaysia. In addition, the other Asian countries had focused their attention on establishing its legal backgrounds along with legal and financial supports (Zali \& Razavi, 2008). Moreover in Iran, the economic, social, cultural development programs and the twenty year prospective document had paid attention to entrepreneurship issue and had started this fact by practical activities such as establishing entrepreneurship centers in universities and developing innovation and entrepreneurship institutions such as universities and growth centers (Ansari \& Salmanizade, 2009). This fact should be noted that only such efforts are not sufficient for preparing backgrounds for entrepreneurship in Iran as this fact requires identifying and removing obstacles in the path of entrepreneurship development in the country. Therefore, this paper has studied and analyzed the motivational and legal barriers and obstacles for developing entrepreneurship in Iran from the point of view of the researchers in the National Conference of Entrepreneurship Management and Regional Development (Ilam University, 2009).

\section{Importance of Research}

The providence of the country's economic, cultural and legal backgrounds is the necessary condition for making efforts for establishing new and small entrepreneurship activities (Talebi and Khaksar, 2011, Lamei, 2007). The legal and lawful systems act as a background for facilitating economic activities. Unfortunately, in developing countries particularly in those countries which the centralized planning system and governmental economy is moving towards free market, the legal and lawful systems cause important problems and obstacles in the path of entrepreneurship and establishing and managing small firms (Feizbakhsh et al, 2003). The scrutinized evidences and studies in Iran show that the governmental laws and regulations not only did not provide proper backgrounds for entrepreneurship and productive activities, but also these laws and regulations acted as a barrier against entrepreneurship growth and consequently, the failure of economic growth and development in Iran (Lamei, 2007). As the understanding and recognizing the obstacles and problems provide the possibility of establishing and applying proper techniques to remove them, the present research will make effort to understand legal obstacles and anti-motivational barriers of entrepreneurship development in Iran.

\section{Research Theoretical Background}

Nowadays, societies are faced with international extensive changes and threats. The changes and fluctuation of the socio-economic system in the present era originated from wonderful technological and scientific progresses in which it leads to the appearance of new requirements, necessities and viewpoints. For replying these needs and going along the mentioned changes, the reliance on the present processes and methods is not sufficient. Therefore, the guarantee and survival of the life of societies requires providing new ways and methods in order to cope with problems. Thus, the new innovation, invention, creation of new products, new processes and methods would be considered as necessities. Policy makers are going to present a model to promote and reinforce entrepreneurship role in multidimensional development with the help of economists in order to achieve this goal (Arasti et al, 2004). The experts and thinkers in various humanities fields are of the same opinion that the entrepreneurship plays the main role in the development and growth of the societies in all of the social, economic and political fields and dimensions. Schumpeter is of opinion that if a society faces depression of entrepreneurship, it will face economic depression as well. Peter Decker believes that the only solution of survival in this changing world is innovation and entrepreneurship in which the improvements of economic performance or growth would be developed (Talebi and Khaksar, 2011). Therefore, the industrialized developed countries could discover the role of the entrepreneurs in economic growth very quickly and adopted proper and supporting policies in order to promote entrepreneurship characteristics of people and promoted the entrepreneurship mood in the different levels of the society following the development of such culture.

In fact nowadays, the innovative and creative people as the entrepreneurs are being considered as the source of great revolutions in industrial, production and servicing fields and in international arena as well. Moreover, their role as the economic development engine and the national heroes and industrial development is the stimulus for investment, the cause of providing employment opportunities, the main choice of technology transmission and the reason beyond removing market disorders in developed countries. The wheels of economic development move on by the entrepreneurship development (Arasti et al, 2004). Therefore, providing backgrounds for entrepreneurship development is vital and this fact requires systematic researches in order to identify and remove the limitations of entrepreneurship development by appropriate policy making and strategies.

Some researchers have been carried out on the entrepreneurship development limitations in and out of the country. In a study on 1840 labor forces in Finland, 7 entrepreneurship limitations such as life conditions, economic risk, lack of skill, social risk, lack of obligation, resources and social support had been identified by the use of statistical analysis techniques. Among these factors, the situation of economic risk and lack of skill regarding the labor force in Finland respectively were the most important entrepreneurship limitations in the country (Zali \& Razavi 2008).

In addition, several researches had been carried out on the obstacles of entrepreneurship development in three dimensions including anti-motivational factors, legal and trade environmental obstacles through an opinion poll of select entrepreneurs in the third festival of top entrepreneurs in 2008. The obtained results of this research show that the situation of business and trade is not appropriate in Iran. Inappropriate situation of business and trade signifies the presence of governmental interference in market, complex problematic regulations, parallel and various supervising organizations and high risk of business and trade activities in Iran. Moreover, another research had been carried out in 2006 in order to analyze the effective environmental (public) factors on entrepreneurship development and entrepreneurial policies from entrepreneurs' viewpoints of the country. Based on this research, 
some factors are effective on the development of entrepreneurship and entrepreneurship policies from entrepreneurs' viewpoints including job (profession) experiences components, management capabilities, bank facilities, export facilities and tax exemptions, financial and non-financial facilities of international sector with other countries, religion, customs, traditions and values, communicational appropriate infrastructures, information technology, accessing information banks, electronic trade and technology and science parks, and the country population structure. (Afshar, et al. of, 2011b).

\section{Research Hypotheses}

Two legal and motivational dimensions were studied and analyzed in the research. Regarding these two dimensions, the following hypotheses were formulated:

H1: The motivational factors had terminated the development of entrepreneurship in Iran, from researchers' viewpoints.

H2: The legal factors had terminated the development of entrepreneurship in Iran, from researchers' viewpoints.

\section{Methodology}

Regarding the formulated and presented hypotheses, the research methodology is survey method. Therefore, the standardized five point's Likert questionnaire which was used by many researchers with a proven reliability and validity was used in order to respond to the research hypotheses after the review of related literature and scrutinizing documents and library sources. The questionnaire contains 24 components in which 11 components related to motivational dimension and the rest (13) related to legal dimension.

The population of the research includes all researchers who had participated in the "National Conference on Entrepreneurship Management and Regional Development' which was held in 2009 in Ilam University. Seventy researchers presented papers in that conference. Thus, the questionnaire was distributed among them by the use of census method.

The statistical calculations and interpretations were carried out by making use of one-sample $\mathrm{T}$ Test for replying to the hypotheses. To rank the factors and components the Freedman test was used and the data were analyzed by using the SPSS software.

\section{Data Analysis}

The characteristics of cognitive population of respondents from age, gender and education aspects depicted in diagrams (1) to (3). As the diagram number (1) shows, most of the researchers $(67.3 \%)$ were 20 to 30 years old. In addition, $83.3 \%$ were male (diagram 2 ) and $69.5 \%$ had postgraduate academic degrees (diagram 3 ).

\section{Insert Figure 1 - here \\ Insert Figure 2 - here \\ Insert Figure 3 - here}

Regarding the Likert five factor questionnaire and specifying number 1 choice for completely disagree, number 5 for completely agree and number 3 as the test value, the results of group T Test would be as in the following 1 and 2 tables;

\section{Insert Table 1 - here}

The results of table 1 show that the mean and standard deviation to motivational factors equal 3.28 and 0.55 in which are greater than the assumed value of $t$ (considered as 3 ) and the amount of $t$ statistic is 3.99 in which its confidence level is 99 percent; $(t=3 / 99, d f=69, P<. / 1)$. Therefore, the null hypothesis is rejected and the alternate hypothesis is accepted; it means that the motivational factors had terminated the development of Iran entrepreneurship from the researchers' viewpoints.

\section{Insert Table 2 - here}

The results of table 2 show that the mean and standard deviation to legal factors equal 3.22 and 0.60 in which are bigger than the assumed value of $\mathrm{t}$ (considered as 3 ) and the amount of t statistic is 2.77 in which its level of confidence is 99 percent; $(t=2 / 75, d f=69, P<. / .1)$. Therefore, the null hypothesis is rejected and the alternate hypothesis is accepted; it means that the legal factors had terminated the development of Iran entrepreneurship from the researchers' viewpoints.

\section{Ranking of Entrepreneurship Barriers}

In this section, the understudied measures in the motivational and legal components as well as two mentioned components were ranked based on mean rank from entrepreneurship researchers' viewpoint by the use of Freedman test. The motivational components include factors which are depicted in table 3 (in mean rank and importance sequence):

\section{Insert Table 3 - here}

The results of table 3 show that the high financial risk taking factor (fear of losing personal capital) specifies the first rank for itself by the highest mean rank. Moreover, much work factor (fear of inability in management due to high work pressure) specifies the last rank as an effective motivational factor in the failure of development in Iran from entrepreneurship researchers' viewpoint. The understudied factors in rules and regulations component depicted in the table 4(in mean rank and importance sequence):

\section{Insert Table 4 - here}


The results of table 4 show that the bank regulations and laws factor (banking interest rate, the required documents and conditions for receiving banking facilities) specifies the first rank for itself by the highest mean rank. In addition, environmental rules and regulations specify the last rank as an effective legal factor in the failure of development in Iran from entrepreneurship researchers' viewpoint.

Moreover, table 5 depicts the total ranking of motivational and legal factors:

\section{Insert Table 5 - here}

The results of table 5 show that the entrepreneurship researchers believe that the motivational factors (with 1.58 mean rank) are more important than legal factors in the failure of entrepreneurship development in Iran.

\section{Conclusion}

It is a necessity to present entrepreneurial skills and training in one hand and identify the obstacles, eliminate their challenges, provide appropriate backgrounds for developing small entrepreneurial practices in order to develop entrepreneurship on the other hand. With respect to the issue of the entrepreneurship limitations and challenges, identifying and studying the present laws and regulations and the motivational factors can be a great help to create small businesses and to promote entrepreneurship activities in the country. The researchers have analyzed and interpreted the motivational and legal barriers in entrepreneurship development path from entrepreneurship thinkers' point of view. The outcome of the test resulted from questionnaire collected data signify that the researchers believed that laws, the present regulations and motivational factors are the obstacles for achieving appropriate entrepreneurship development in the country. Regarding ranking of the effective factors on the failure of entrepreneurship development in Iran, the high financial risk taking factor (fear of losing personal capital) specifies the first rank for itself by the highest mean rank and much work factor (fear of inability in the management due to high work pressure) specifies the last rank as effective motivational factors. Moreover, the bank regulations and laws factor (banking interest rate, the required documents and conditions for receiving banking facilities) specifies the first rank for itself by the highest mean rank and environmental rules and regulations specify the last rank as effective legal factors on the failure of the country's entrepreneurship development from entrepreneurship researchers' viewpoint. In addition, entrepreneurship researchers are of opinion that the motivational factors are more important than legal factors in the failure of entrepreneurship development in Iran. Therefore, it is recommended that state organizations and institutions develop appropriate rules for maximum efficiency of the entrepreneurial activities and reduce the restrictions of these rules as much as possible, too.

\section{Recommendations for further researches}

- Particular care and consideration to motivational and legal aspects of entrepreneurship in family businesses

- Particular care and consideration to motivational and legal aspects of entrepreneurship in home businesses.

- $\quad$ Study the other effective factors on entrepreneurs' success

\section{References}

Afshar Jahanshahi, A., Khaksar, S.M.S., Jamali Paghaleh, M., \& Pitamber, B.K. (2011a). The Application of Electronic Commerce among Small and Medium Enterprises: from Business Processes View. International Journal of Business and Social Science, Vol. 2 No. 5; (Special Issue -March 2011)

Afshar Jahanshahi, A., Nawaser, K., Khaksar, S.M.S., \& Kamalian, A. (2011b). The Relationship between Government Policy and the Growth of Entrepreneurship in the Micro, Small \& Medium Enterprises of India. $J$. Technol. Manag. Innov, 2011, Volume 6, Issue 1, pp.66-77

Ahl, H. (2004). The scientific reproduction of gender inequality: A discourse analysis of research texts on women's entrepreneurship. Copenhagen, Denmark: CBS Press.

Aidis R, Estrin, S \& Mickiewicz, T. (2008). Institutions and entrepreneurship development in Russia: A comparative perspective. Journal of Business Venturing, No 23, pp. 656-672. http://dx.doi.org/10.1016/j.jbusvent.2008.01.005

Ansari, M.T., \& Soleymani Zadeh A. (2009). Study the environmental factors affecting entrepreneurship development from the country entrepreneur's viewpoint. Journal of Management, No. 1.

Arasti Z. Z. Golard P \& Vakiri, M. R. (2004). The role of entrepreneurship in developing countries logistic, the first national conference of logistic and supply chain.

Benzing, C., \& Chu, H. M. (2005). Entrepreneurial Behavior in Andhra Pradesh, India, Proceedings of the Association of Global Business 2005. Miami Beach, Florida.

Benzing, C., Chu, H. M., and Kara, O. (2009). Entrepreneurs in Turkey: A Factor Analysis of Motivations, Success Factors and Problems. Journal of Small Business Management, Vol. 47, No. 1, pp. 58-91. http://dx.doi.org/10.1111/j.1540-627X.2008.00262.x

Capello, R. (2002). Entrepreneurship and Spatial Externalities: Theory and Measurement. Annals of Regional Science, 36 (3): 387-402. http://dx.doi.org/10.1007/s001680200106

Carter, N.M., and Allen, K.R. (1997). Size determinants of women-owned businesses: Choice or barriers to resources? Entrepreneurship and Regional Development, 9(3), pp.211-220. http://dx.doi.org/10.1080/08985629700000012 
Chell, E., and Baines, S. (1998). Does gender affect business "performance"? A study of micro businesses in business services in the UK. Entrepreneurship and Regional Development, 10(2), pp.117-135. http://dx.doi.org/10.1080/08985629800000007

Chowdhury, Mohammed. (2007). Overcoming entrepreneurship development constraints: the case of Bangladesh. Journal of Enterprising Communities: People and Places in the Global, Vol. 1 No. 3, pp. 240-251. http://dx.doi.org/10.1108/17506200710779549

Daily, C. M. et al. (2002). Governance and Strategic Leadership in Entrepreneurial Firms. Journal of Management, Vol. 28, No. 3, pp. 387-412. http://dx.doi.org/10.1177/014920630202800307

Desai, Vasant. (2005). Dynamics of Entrepreneurial Development and Management. Mumbai: Himalaya Publishing House.

Faizbakhsh, S A, Tajrishi, A T K, \& Amini, R. (2003). Targets of Entrepreneurship and small businesses development, Rahyaft No. 29.

GEM. (2008). Global Entrepreneurship Monitor 2008 Executive Report. [Online] Available: www.gemconsortium.org (15 January, 2009).

Gupta, V \& York, A. (2008). Attitudes toward entrepreneurship and small business. Journal of Enterprising Communities: People and Places in the Global, Vol. 2 No. 4, pp. 348-366. http://dx.doi.org/10.1108/17506200810913917

Harandi B, Sarmad A \& Hejazi E. (2008). Research Methodology in Behavioral Sciences. Agah Publications. Tehran.

Helpman, E. (2004). The Mystery of Economic Growth. Cambridge: Belknap Press.

Jeddi, S., \& Zanjani, M. (2001). The obstacles of entrepreneurship development in Iranian companies, external and internal factors. Management of Engineering and Technology, 1, p. 318.

Khaksar S.M.S, Afshar Jahanshahi, A., \& Nawaser, K. (2010). Study of the relation of Customer Service and Entrepreneurial Opportunities. Asian Journal of Management Research, Volume 1 Number 1, pp.200-215

Kourilsky, M.L. (1995). Entrepreneurship Education: Opportunity in Search of Curriculum. Business Education Forum, 50(10). Pp.11-15

Koven, S. G., and Lyons, T. S. (2003). Economic Development: Strategies for State and Local Practice. Washington, DC: International City/County Management Association.

Lamei, B. (2007). Legal barriers to the growth of entrepreneurship in the Small Industries of Iran. Tehran, 1 (2).

Morris, M.H. (2001). Entrepreneurship is economic development is entrepreneurship. Journal of Developmental Entrepreneurship, Vol. 6 No. 3, pp. v-vi.

Nijkamp, P. (2003). Entrepreneurship in a Modern Network Economy. Regional Studies, 37 (4): 395-405. http://dx.doi.org/10.1080/0034340032000074424

Nijkamp, P., and R. Stough (eds). (2002). Entrepreneurship and Regional Economic Development. Annals of Regional Science, 36 (3): 369-71. http://dx.doi.org/10.1007/s001680200118

Olomi, D.R. (2001). Entrepreneurial Motivation in a Developing Country Context: Incidence, Antecedents and Consequences of Growth-seeking Behavior among Tanzanian Owner-Managers. Ph.D. dissertation, University of Dar es Salaam .

Organization for Economic Co-operation and Development (OECD). (2002). Benchmarking: Fostering Firms Creation and Entrepreneurship. Paris: OECD Directorate for Science, Technology and Industry.

Porter, M. (2003). The Economic Performance of Regions. Regional Studies, 37 (6/7): 549-78.

Robichaud, Y., McGraw, E., and Roger, A. (2001). Toward the Development of a Measuring Instrument for Entrepreneurial Motivation. Journal of Developmental Entrepreneurship, Vol. 6, No. 1, pp. 189-202.

Roy, M. A., \& Wheeler, D. (2006). A Survey of Micro-Enterprise in Urban West Africa: Drivers Shaping the Sector. Development in Practice, Vol. 16, No. 5, pp. 452-464. http://dx.doi.org/10.1080/09614520600792432

Schmiemann, M. (2008). Enterprises by Size and Class: Overview of SMEs in the EU. Statistics in Focus, No. 31, Luxembourg: Eurostat.

Shane, S. (2003). A General Theory of Entrepreneurship. Cheltenham: Edward Elgar.

Shane, S. (2008). The illusions of Entrepreneurs: The Costly Myths that Entrepreneurs, Investors and Policy Makes Live By. Yale University Press, New Haven, CT.

Shane, S., and S. Venkataraman (2000). The Promise of Entrepreneurship as a Field of Research. Academic Management Review, 96: 98-121.

Stefanovic, I., Milosevic, D., and Miletic, S. (2009). Significance and Development Problems of SMEs in Contemporary Market Economy. Serbian Journal of Management, Vol. 4, No. 1, pp. 127-136.

Sudha, G.S. (2007). Dynamics of Business Entrepreneurship. Jaipur: RBSA Publisher.

Talebi, K., and Khaksar, S.M.S. (2011). The process of formation of manufacturing in small and medium-sized enterprises in Iran. World Applied Sciences Journal, 14 (1): 157-166. 
Zahra, S., \& Dess, G. (2001). Entrepreneurship as a field of research: encouraging dialogue and debate. Academy of Management Review, 26(1), 8-11. http://dx.doi.org/10.5465/AMR.2001.4011916

Zali, M R \& Razavi, S M. (2008). Research on entrepreneurship development obstacles in Iran, Entrepreneurship College, Tehran University.

Table 1. Results of single-group/one sample t-test for motivational factors

\begin{tabular}{|l|l|l|l|l|l|l|l|}
\hline Test value=3 & Quantity & Mean & $\begin{array}{l}\text { Standard } \\
\text { Deviation }\end{array}$ & $\begin{array}{l}\text { T } \\
\text { Value }\end{array}$ & $\begin{array}{l}\text { Degree } \\
\text { Freedom }\end{array}$ & $\begin{array}{l}\text { Level of } \\
\text { Confidence }\end{array}$ \\
\hline Motivational Factors & 70 & 3.28 & 0.55 & 3.99 & 69 & 0.01 \\
\hline
\end{tabular}

Table 2. Results of single-group/one sample t-test for legal factors

\begin{tabular}{|c|c|c|c|c|c|c|}
\hline \multicolumn{7}{|l|}{ Test value $=3$} \\
\hline Variable & Quantity & Mean & $\begin{array}{l}\text { Standard } \\
\text { Deviation }\end{array}$ & $\mathrm{T}$ Value & $\begin{array}{l}\text { Degree of } \\
\text { Freedom }\end{array}$ & $\begin{array}{c}\text { Level of } \\
\text { Confidence }\end{array}$ \\
\hline Legal Factors & 70 & 3.22 & 0.60 & 2.75 & 69 & 0.01 \\
\hline
\end{tabular}

Table 3. Entrepreneurship researchers' attitude towards the motivational components

\begin{tabular}{|c|l|c|}
\hline No. & \multicolumn{1}{|c|}{ Components } & Mean Rank \\
\hline 1 & Much financial risk (fear of losing personal capital) & 8.79 \\
\hline 2 & Financial obstacles (concerns originated from the lack of legal necessities providence) & 7.48 \\
\hline 3 & $\begin{array}{l}\text { Accessing financial resources for investment (fear of disability for providing sufficient } \\
\text { financial resources for establishing business or trade) }\end{array}$ & 7.46 \\
\hline 4 & Corruption (official corruption in society) & 6.32 \\
\hline 5 & Lack of skills (fear of having no skills, sufficient and proper experience) & 6.12 \\
\hline 6 & Social dangers/expenses (concerns originated from probable failure of social security) & 6.09 \\
\hline 7 & Market demand (fear of no demand for receiving or purchasing services or goods) & 5.65 \\
\hline 8 & Gender (fear of failure in establishing business or trade by women) & 5.21 \\
\hline 9 & Fear of defeat (fear of sarcasm or blames in family or society arousing by defeat) & 4.77 \\
\hline 10 & Competition (severe competition in business activities) & 4.44 \\
\hline 11 & Much work (fear of inability in management due to high work pressure) & 3.66 \\
\hline
\end{tabular}

Table 4. Entrepreneurship researchers' attitude towards the components of rules and regulations

\begin{tabular}{|l|l|l|}
\hline No. & Components & Mean Rank \\
\hline 1 & $\begin{array}{l}\text { Bank regulations and laws factor (banking interest rate, the required documents and } \\
\text { conditions for receiving banking facilities) }\end{array}$ & 9.84 \\
\hline 2 & Trade Law (its non-supportive nature and complexity) & 8.98 \\
\hline 3 & Governmental monopolies originated from governmental rules and regulations & 8.60 \\
\hline 4 & $\begin{array}{l}\text { Tax Regulations (their non-supportive nature, complexity, the rate of tax on companies } \\
\text { income) }\end{array}$ & 8.12 \\
\hline 5 & Labor Law (no support of entrepreneurship) & 7.91 \\
\hline 6 & $\begin{array}{l}\text { Rules and regulations related to bankruptcy (severe negative attitude towards labor } \\
\text { defeat) }\end{array}$ & 7.33 \\
\hline 7 & Custom regulations, laws and tariffs & 6.65 \\
\hline 8 & Municipality regulations (municipal tolls) & 6.53 \\
\hline 9 & Rules and regulations related to export and import & 6.47 \\
\hline 10 & Rules and regulations related to copyright and invention recordings & 5.95 \\
\hline 11 & $\begin{array}{l}\text { Regulation of companies recordings and registrations (the expenditure of company } \\
\text { registration, duration of registration, complexity of rules and the related laws) }\end{array}$ & 5.81 \\
\hline 12 & Regulations related to tax collection & 5.23 \\
\hline 13 & Environmental rules and regulations & 3.58 \\
\hline
\end{tabular}


Table 5. Comparison of entrepreneurship researchers' attitude towards variables

\begin{tabular}{|c|l|l|}
\hline No. & \multicolumn{1}{|c|}{ Components } & Mean Rank \\
\hline $\mathbf{1}$ & Motivational Factors & 1.58 \\
\hline $\mathbf{2}$ & Legal Factors & 1.42 \\
\hline
\end{tabular}

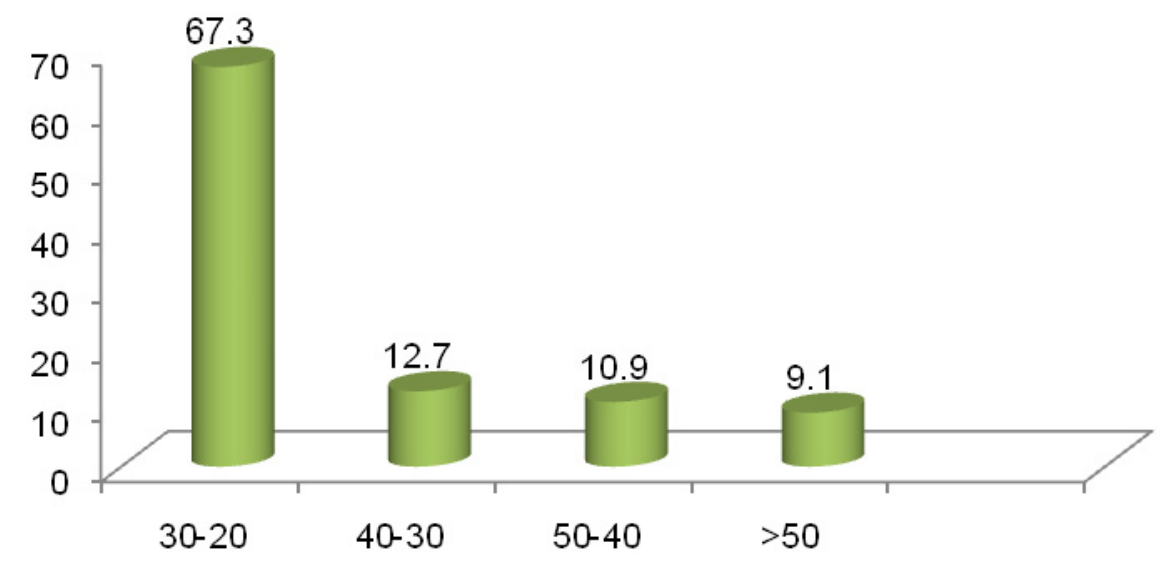

Figure 1. Age of experts

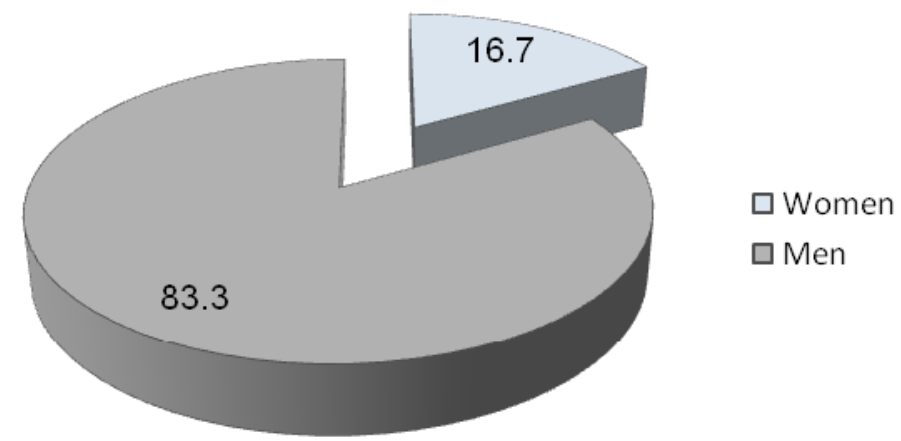

Figure 2. Sex

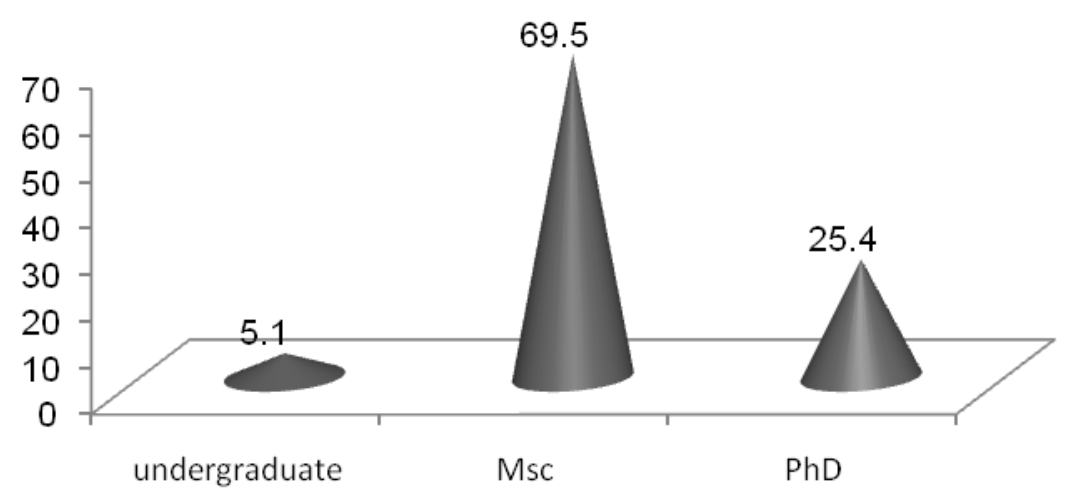

Figure 3. Education 